\title{
ANALISIS PERPUTARAN PIUTANG, PIUTANG RATA-RATA DAN RASIO PIUTANG ATAS PENDAPATAN TERHADAP PROFITABILITAS PADA PDAM TIRTA BUMI SENTOSA KABUPATEN KEBUMEN
}

\author{
Wenny Marlini ${ }^{1}$ dan Mega Widya Utami \\ Politeknik Dharma Patria Kebumen \\ wewenlin3832@gmail.com
}

\begin{abstract}
To determine the effectiveness of the management of accounts receivable, one of them by looking at the management of accounts receivable that is by calculating receivables turnover, average accounts receivable and the ratio of revenue. The calculation aims to determine how the performance of its receivables management.

PDAM to manage accounts still less than optimal seen from the accounts receivable turnover decreased means that the longer the company's capital back into cash, average accounts receivable increase means the greater the greater the age of accounts receivable collectibility of accounts receivable and ratio of receivables from increased revenues and reduced income when receivables increase.

The solution is to give the author PDAM must control receivables and anticipate the existence of doubtful receivables, then the company needs to provide policies in collection of accounts receivable which the company hopes that customers deposit the payment on time.

Results calculation accounts receivable turnover in 2012 was amounted to 5,7 times, and in 2013 was amounted to 5.3 times the mean decreases, average accounts receivable in 2012 was amounted 63 days and in 2013 was amounted to 69 days means increased, and the ratio of receivables on income in 2012 was amounted to $0.1744 \%$ and in 2013 was amounted to $0.1888 \%$ mean increase. Receivables increased revenue decreased. Results of analysis of receivables turnover PDAM Tirta Bumi Sentosa Kabupaten Kebumen not good, average receivables including unfavorable, and the ratio of receivables on income analysis results are less good too. It can be concluded that the receivables on PDAM Tirta Bumi Sentosa Kabupaten Kebumen not good.
\end{abstract}

Keywords : Receivables Turnover, Average Receivables, Ratio of Receivables on Income.

\begin{abstract}
To determine the effectiveness of the management of accounts receivable, one of them by looking at the management of accounts receivable that is by calculating receivables turnover, average accounts receivable and the ratio of revenue. The calculation aims to determine how the performance of its receivables management.

PDAM to manage accounts still less than optimal seen from the accounts receivable turnover decreased means that the longer the company's capital back into cash, average accounts receivable increase means the greater the greater the age of accounts receivable collectibility of accounts receivable and ratio of receivables from increased revenues and reduced income when receivables increase.

The solution is to give the author PDAM must control receivables and anticipate the existence of doubtful receivables, then the company needs to provide policies in collection of accounts receivable which the company hopes that customers deposit the payment on time.

Results calculation accounts receivable turnover in 2012 was amounted to 5,7 times, and in 2013 was amounted to 5.3 times the mean decreases, average accounts receivable in 2012 was amounted 63 days and in 2013 was amounted to 69 days means increased, and the ratio of receivables on income in 2012 was amounted to $0.1744 \%$ and in 2013 was amounted to $0.1888 \%$ mean increase. Receivables increased revenue decreased. Results of analysis of receivables turnover PDAM Tirta Bumi Sentosa Kabupaten Kebumen not good, average receivables including unfavorable, and the ratio of receivables
\end{abstract}


on income analysis results are less good too. It can be concluded that the receivables on PDAM Tirta Bumi Sentosa Kabupaten Kebumen not good.

Keywords : Receivables Turnover, Average Receivables, Ratio of Receivables on Income.

\section{A. PENDAHULUAN}

\section{Latar Belakang Masalah}

PDAM Tirta Bumi Sentosa Kabupaten Kebumen berkewajiban memenuhi kebutuhan air bersih bagi masyarakat. Masyarakat menggunakan air bersih tersebut terlebih dahulu baru kemudian membayarnya setiap bulan pada perusahaan. Oleh karena itu, pembayaran tagihan yang belum dibayar setiap bulannya dari pelanggan dicatat sebagai piutang. Perusahaan mendapatkan pendapatan dari penjualan air bersih tersebut. Pendapatan penjualan air bersih diakui dan dicatat berdasarkan rekening tagihan yang diterbitkan pada bulan yang bersangkutan.

Piutang merupakan tagihan yang akan timbul atas penyerahan barang atau jasa saat ini yang dilakukan perusahaan kepada pelanggan yang akan dilunasi dengan uang dimasa yang akan datang.

Dalam modul keuangan dikatakan bahwa "Perputaran piutang digunakan untuk mengukur kemampuan perusahaan dalam mengelola dana yang tertanam dalam piutang yang berputar pada suatu periode tertentu". Jadi perputaran piutang digunakan untuk mengetahui berapa kali dalam satu periode, piutang akan berputar kembali menjadi kas. Rasio perputaran piutang memberikan pandangan mengenai kualitas piutang perusahaan dan seberapa berhasilnya perusahaan dalam penagihannya. Semakin cepat perputaran piutangnya berarti menandakan bahwa semakin cepat modal kembali.

Selain perputaran piutang yang digunakan sebagai indikator terhadap efisien atau tidaknya piutang, ada indikator lain yaitu rata-rata pengumpulan piutang. Rata-rata pengumpulan piutang digunakan untuk mengukur periode rata-rata yang diperlukan untuk mengumpulkan piutang. Semakin besar umur piutang, semakin besar pula kemungkinan piutang tak tertagihnya.

Tingkat profitabilitas yang tinggi menunjukkan tingkat efisiensi perusahaan. Profit yang diperoleh tidak hanya digunakan untuk membiayai kegiatan operasional perusahaan saja, tetapi juga digunakan untuk ekspansi perusahaan melalui berbagai kegiatan pada masa yang akan datang. Kemudian yang lebih penting lagi, apabila suatu perusahaan terus menerus memperoleh keuntungan maka ini berarti kelangsungan hidup perusahaan tersebut akan terjamin. Salah satu cara meningkatkan profitabilitas perusahaan dengan cara mengelola piutang perusahaan seefektif mungkin.

Untuk mengetahui efektifitas pengelolaan piutang, salah satunya dengan melihat perputaran piutang pada perusahaan. Semakin tinggi tingkat perputaran piutang menandakan semakin efektif piutangnya. Apabila pengelolaan piutang kurang efektif maka profitabilitas perusahaan kurang baik. Karena piutang yang bertambah menyebabkan pendapatan perusahaan berkurang. Sehingga perusahaan perlu meningkatkan kebijakan kredit yang telah ditetapkan oleh perusahaan.

\section{Pokok Permasalahan}

Pokok permasalahan dalam penelitian ini adalah "Bagaimana perputaran piutang, piutang ratarata dan rasio piutang atas pendapatan terhadap profitabilitas pada PDAM Tirta Bumi Sentosa Kabupaten Kebumen?"

\section{Pertanyaan Penelitian}

Berdasarkan latar belakang diatas, maka rumusan masalah yang akan dijadikan pedoman penelitian ini adalah :

a. Berapa perputaran piutang pada PDAM Tirta Bumi Sentosa Kabupaten Kebumen?

b. Berapa piutang rata-rata pada PDAM Tirta Bumi Sentosa Kabupaten Kebumen?

c. Berapa rasio piutang atas pendapatan pada PDAM Tirta Bumi Sentosa Kabupaten Kebumen?

d. Bagaimana pengaruh perputaran piutang, piutang rata-rata dan rasio piutang atas pendapatan pada Tirta Bumi Sentosa Kabupaten Kebumen terhadap profitabilitas?

\section{Tujuan Penelitian}

Adapun maksud dan tujuan penelitian ini adalah:

a. Mengetahui perputaran piutang pada PDAM Tirta Bumi Sentosa Kabupaten Kebumen. 
b. Mengetahui piutang rata-rata pada PDAM Tirta Bumi Sentosa Kabupaten Kebumen .

c. Mengetahui rasio piutang atas pendapatan pada PDAM Tirta Bumi Sentosa Kabupaten Kebumen.

d. Mengetahui pengaruh perputaran piutang, piutang rata-rata dan rasio piutang atas pendapatan pada Tirta Bumi Sentosa Kabupaten Kebumen terhadap profitabilitas.

\section{B. KERANGKA PEMIKIRAN}

\section{Kajian Ilmiah}

1. Pengertian Piutang

Piutang adalah hak tagihan kepada pihak lain yang berutang kepada perusahaan. Jika jumlah piutang semakin besar kemungkinan munculnya piutang tak tertagih semakin besar pula. Berdasarkan definisi-definisi yang ada dapat disimpulkan bahwa "Piutang adalah hak klaim atau tagihan berupa uang atau bentuk lainnya kepada seseorag atau suatu perusahaan yang timbul atas penyerahan barang atau jasa saat ini yang dilakukan perusahaan kepada pelanggan yang akan dilunasi dengan uang dimasa yang akan datang".

2. Perputaran Piutang

Menurut Martono (2002:75) adalah "Perputaran piutang adalah rasio yang digunakan untuk mengetahui kemampuan yang tertanam dalam piutang berputar dalam periode tertentu yaitu dengan membagi total penjualan kredit (netto) dengan piutang rata-rata“. Semakin cepat perputaran piutang, semakin efektif perusahaan dalam mengelola piutangnya. Tingkat perputaran atau receivable turnover dapat diketahui dengan cara membagi penjualan kredit dengan jumlah rata - rata piutang “.

3. Piutang rata-rata

Rasio ini mengukur efisiensi pengolahan piutang perusahaan, serta menunjukkan berapa lama waktu yang diperlukan untuk melunasi piutang atau merubah piutang menjadi kas. Rata-rata umur piutang ini dihitung dengan membandingkan jumlah piutang dengan penjualan perhari. Dimana penjualan perhari yaitu penjualan dibagi 360. Rata-rata pengumpulan piutang digunakan untuk mengukur periode rata-rata yang diperlukan untuk mengumpulkan piutang

4. Pendapatan penjualan

Pendapatan adalah hasil penjualan barang dan jasa yang dibebankan kepada langganan/ mereka yang menerima.

Penjualan merupakan kegiatan yang dilakukan oleh penjual dalam menjual barang dan jasa dengan harapan akan memperoleh laba dari adanya transaksi-transaksi tersebut dan penjualan dapat diartikan sebagai pengalihan atau pemindahan hak kepemilikan atas barang atau jasa dari pihak penjual ke pembeli.

5. Profitabilitas

Pengertian profitabilitas menurut Syafri (2008:304) "Rasio profitabilitas merupakan rasio yang menggambarkan kemampuan perusahaan dalam mendapatka laba melalui semua kemampuan dan sumber yang ada seperti kegiatan penjualan, kas, modal, jumlah karyawan, jumlah cabang dan sebagainya".

6. Tujuan dan manfaat rasio profitabilitas

Rasio profitabilitas juga memiliki tujuan dan manfaat, tidak hanya bagi pemilik usaha atau manajemen saja, tetapi juga bagi pihak di luar perusahaan, terutama pihak-pihak yang memiliki hubungan atau kepentingan dengan perusahaan.

1. Tujuan profitabilitas

Tujuan penggunaan rasio profitabilitas bagi peusahaan, maupun bagi pihak luar perusahaan, yaitu:

a. Untuk mengukur atau menghitung laba yang diperoleh perusahaan dalam satu periode tertentu.

b. Untuk menilai posisi laba perusahaan tahun sebelumnya dengan tahun sekarang.

c. Untuk menilai perkembangan laba dari waktu ke waktu.

d. Untuk menilai besarnya laba bersih sesudah pajak dengan modal sendiri.

e. Untuk mengukur produktivitas seluruh dana perusahaan yang digunakan baik modal pinjaman maupun modal sendiri.

2. Manfaat dari rasio profitabilitas:

a. Mengetahui besarnya tingkat laba yang diperoleh perusahaan dalam satu periode.

b. Mengetahui posisi laba perusahaan tahun sebelumnya dengan tahun sekarang. 
c. Mengetahui perkembangan laba dari waktu ke waktu.

d. Mengetahui besarnya laba bersih sesudah pajak dengan modal sendiri.

e. Mengetahui produktivitas dari seluruh dana perusahaan yang digunakan baik modal pinjaman maun modal sendiri.

7. Jenis-jenis Rasio Profitabilitas

Sesuai dengan tujuan yang hendak dicapai, terdapat beberapa jenis rasio profitabilitas yang dapat digunakan. Masing-masing jenis rasio profitabilitas digunakan untuk menilai serta mengukur posisi keuangan perusahaan dalam suatu periode tertentu atau untuk beberapa periode.

Dalam rasio keuntungan atau profitability ratios ini ada beberapa rumusan yang digunakan di antaranya adalah :
a. Gross Profit Margin
b. Operating Profit Margin
c. Operating Ratio
d. Net Profit Margin
e. Return On Assets
f. Return On Equity
g. Return On Investment
h. Earning Per Share (Eps)

\section{Kerangka Pemikiran}

Adapun kerangka pikir yang digunakan dalam penelitian ini adalah sebagai berikut tampak pada gambar di bawah ini:

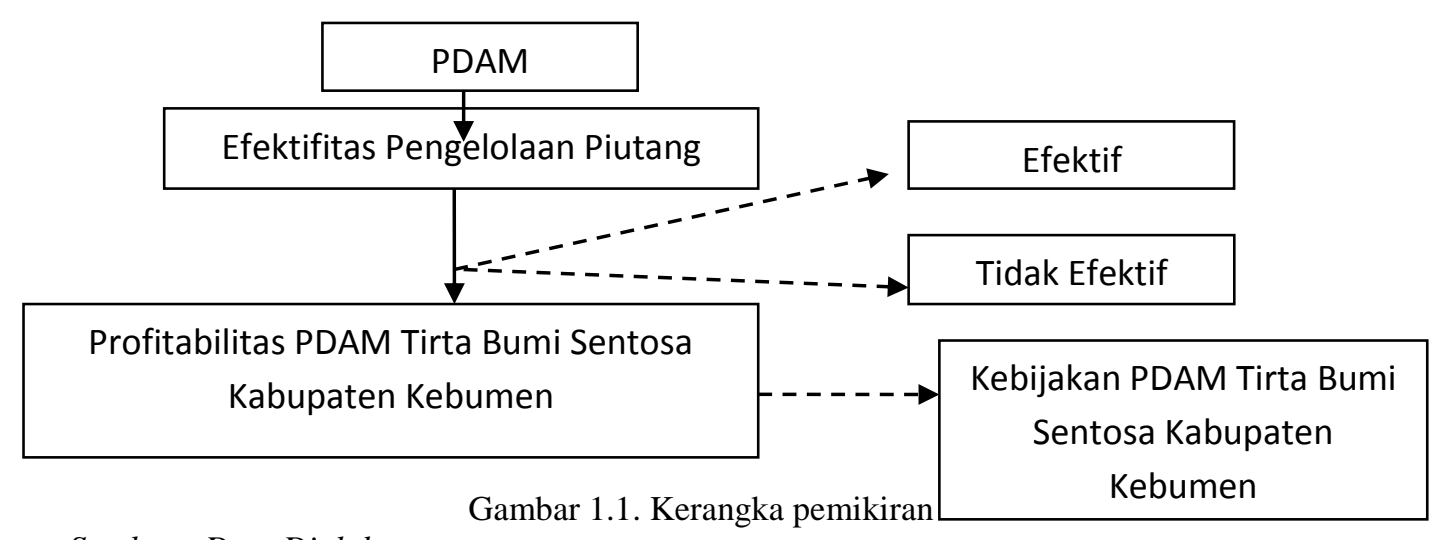

Sumber : Data Diolah

Penjelasan:

PDAM Tirta Bumi Sentosa Kabupaten Kebumen adalah perusahaan milik pemerintah Kabupaten Kebumen yang bergerak dalam bidang pelayanan air minum kepada masyarakat di suatu wilayah tertentu. Pengelolaan piutang pada PDAM bisa efektif bisa juga tidak efektif. Apabila pelanggan membayar tagihan piutangnya kepada perusahaan tepat waktu maka dikatakan efektif. Sebaliknya, apabila pelanggan tidak membayar tagihannya tepat waktu atau melebihi batas waktu yang ditetapkan oleh perusahaan setiap bulannya maka dikatakan tidak efektif. Efektivitas pengelolaan piutang akan dapat berpengaruh pada profitabilitas perusahaan karena perusahaan mendapatkan pendapatan dari tagihan pembayaran air bersih yang dibayar oleh pelanggan. Dalam hal ini penulis meneliti apakah di PDAM Tirta Bumi Sentosa Kabupaten Kebumen pengelolaan piutangnya sudah efektif atau belum. Hal ini karena akan dapat dijadikan bahan pertimbangan untuk mengambil keputusan atau kebijakan oleh perusahaan. Ketika tidak efektif, misalnya perusahaan harus memperbaiki syarat pembayaran kreditnya. Apabila sudah efektif perusahaan dapat mempertahankan kebijakan yang telah ditetapkan sebelumnya oleh perusahaan.

\section{METODE PENELITIAN}

\section{Metode Penelitian dan Teknik pengumpulan data}

1. Metode Penelitian 
Untuk menjawab permasalahan yang diteliti, diperlukan teknik yang digunakan dalam penulisan penelitian. Metode penelitian yang digunakan yaitu metode analisa kuantitatif. Metode kuantitatif adalah suatu proses menemukan pengetahuan yang menggunakan data berupa angka sebagai alat menganalisis keterangan mengenai apa yang ingin diketahui.

2. Definisi Operasional Variabel

Variabel adalah suatu atribut sifat dan objek yang mempunyai variasi tertentu yang ditetapkan oleh peneliti untuk dipelajari dan diteiti yaitu:

a. Variabel bebas

Variabel bebas adalah variabel yang terjadi mendahului dan mempengaruhi variabel lainnya. Dalam penelitian ini yang menjadi variabel bebasnya adalah "efektivitas pengelolaan piutang atas pendapatan pada PDAM Tirita Bumi Sentosa Kabupaten Kebumen"

b. Variabel tidak bebas

Variabel tidak bebas adalah variabel yang dipengaruhi atau disebabkan oleh variabel lainnya.

Dalam penelitian ini yang menjadi variabel tidak bebasnya adalah "profitabilitas pada PDAM

Tirita Bumi Sentosa Kabupaten Kebumen”

3. Populasi dan Sampel Penelitian

a. Populasi

Populasi adalah keseluruhan dari suatu objek yang diteliti. Dari laporan tersebut diketahui bahwa polpulasi merupakan keseluruhan subjek penelitian yang dapat ditarik kesimpulan. Populasi dalam penelitian ini adalah efektivitas pengelolaan piutang atas pendapatan terhadap profitabilitas pada PDAM Tirita Bumi Sentosa Kabupaten Kebumen.

b. Sampel

Sampel adalah bagian dari populasi yang memiliki sifat-sifat yang sama dari objek yang merupakan sumber data. Sampel dalam penelitian ini adalah pengelolaan piutang atas pendapatan pada PDAM Tirita Bumi Sentosa Kabupaten Kebumen

4. Teknik Pengmpulan Data

Untuk memperoleh data-data yang diperlukan dalam penelitian ini, penulis menggunakan teknik pengumpulan data sebagai berikut:

a. Penelitian lapangan

a) Dokumentasi

Teknik dokumentasi ini dilakukan dengan cara mencatat dokumen-dokumen, arsip-arsip maupun data lain yang terkait dengan masalah yang diteliti.

b) Wawancara

Wawancara dilakukan dengan cara tanya jawab antara peneliti dengan salah satu pegawai pada perusahaan.

b. Penelitian kepustakaan

Penelitian ini dimaksudkan untuk memperoleh landasan teori guna mendukung data-data yang diperoleh. Studi kepustakaan adalah penelitian dengan cara mempelajari dan membaca literaturliteratur, catatan-catatan, dan laporan-laporan yang ada hubungannya dengan permasalahan yang menjadi objek penelitian.

\section{HASIL DAN PEMBAHASAN}

1. Analisis Deskriptif

Data Laporan Keuangan

Laporan keuangan pada PDAM Tirta Bumi Sentosa Kabupaten Kebumen diantaranya disajikan dalam bentuk neraca dan laporan laba rugi. Di dalam neraca terdapat piutang usaha yang termasuk dalam asset lancar. Piutang pada PDAM Tirta Bumi Sentosa Kabupaten Kebumen diperoleh dari ketika masyarakat menggunakan air bersih tersebut terlebih dahulu baru kemudian membayarnya setiap bulan pada perusahaan. Pembayaran tagihan yang belum dibayar setiap bulannya dari pelanggan yang kemudian dicatat sebagai piutang. Untuk mengetahui piutang pada PDAM Tirta Bumi Sentosa Kabupaten Kebumen, di bawah ini akan disajikan tabel nearaca:

Tabel 2.1 Tabel Neraca per 31 Desember 2012 dan 2013 di PDAM Tirta Bumi Sentosa Kabupaten Kebumen

\begin{tabular}{|c|c|c|c|}
\hline Keterangan & Referensi & Tahun 2012 (Rp) & Tahun 2013 (Rp) \\
\hline 1 & 2 & 3 & 4 \\
\hline Aset & & &
\end{tabular}




\begin{tabular}{|l|r|r|r|} 
Aset Lancar & & & \\
Kas dan Bank & 1.1 & $4.762 .982 .000,04$ & $754.623 .691,52$ \\
Deposito & 1.2 & $3.670 .000 .000,00$ & $9.000 .000 .000,00$ \\
Piutang Usaha & 2).(4).1.3 & $2.132 .755 .805,00$ & $2.459 .374 .425,00$ \\
Penyisihan Piutang Usaha & 2).(4).1.4 & $-406.084 .587,41$ & $-412.236 .370,41$ \\
Piutang Pegawai & 2).(4).1.5 & $73.955 .620,00$ & - \\
Piutang Lain-lain & 2).(4).1.6 & $198.477 .933,00$ & - \\
Persediaan & 2).(5).1.7 & $1.143 .977 .654,72$ & $1.164 .460 .208,01$ \\
Biaya Dibayar Dimuka & 2).(3).1.8 & $630.745 .107,43$ & $10.970 .555,56$ \\
Uang Muka Kerja & 2).(3).1.9 & $261.060 .380,00$ & $10.300 .000,00$ \\
\hline Jumlah Aset Lancar & & $\mathbf{1 2 . 4 6 7 . 8 6 9 . 9 1 2 , 7 8}$ & $\mathbf{1 2 . 9 8 7 . 4 9 2 . 5 0 9 , 6 8}$ \\
\hline Aset Tetap & & & \\
Tanah & & $806.451 .918,30$ & $975.282 .918,30$ \\
Instalasi Sumber Air & & $1.319 .838 .527,02$ & $1.319 .838 .527,02$ \\
Instalasi Pompa Air & & $3.667 .166 .547,38$ & $4.141 .557 .947,38$ \\
Instalasi Pengolahan Air & & $6.525 .160 .169,69$ & $6.573 .988 .169,69$ \\
& & $21.811 .282 .702,03$ & \\
Instalasi Transmisi dan Distribusi & & $1.120 .095 .078,82$ & $1.201 .499 .348,82$ \\
Bangunan / Gedung & & $268.885 .186,13$ & $268.885 .186,13$ \\
Peralatan dan Perlengkapan & & $1.157 .234 .372,88$ & $1.319 .734 .372,88$ \\
\hline Kendaraan / Alat Angkut & &
\end{tabular}

\begin{tabular}{|c|c|c|c|}
\hline 1 & 2 & 3 & 4 \\
\hline $\begin{array}{l}\text { Inventaris Kantor } \\
\text { Harga Perolehan } \\
\text { Akumulasi Penyusutan } \\
\end{array}$ & & $\begin{array}{r}745.270 .979,83 \\
\mathbf{3 7 . 4 2 1 . 3 8 5 . 4 8 2 , 0 8} \\
(26.232 .456,308,21) \\
\end{array}$ & $\begin{array}{r}854.929 .704,83 \\
\mathbf{3 9 . 8 4 4 . 3 1 5 . 0 2 6 , 9 3} \\
-27.782 .693 .769,28 \\
\end{array}$ \\
\hline Nilai Buku Aset Tetap & 2).(7).1.10 & 11.188.929.173,87 & $12.061 .621 .257,65$ \\
\hline $\begin{array}{l}\text { Aset Lainnya } \\
\text { Piutang Lain-lain } \\
\text { Pembayaran Dimuka Kepada } \\
\text { PEMDA }\end{array}$ & $\begin{array}{l}\text { 2).(7).1.11 } \\
\text { 2).(7).1.12 }\end{array}$ & - & $\begin{array}{l}198.477 .933,00 \\
490.055 .750,00 \\
\end{array}$ \\
\hline Jumlah Aset Lain-lain & & - & $688.533 .683,00$ \\
\hline Jumlah Aset & & $23.656 .799 .086,65$ & $25.737 .647 .450,33$ \\
\hline $\begin{array}{l}\text { Kewajiban dan Ekuitas } \\
\text { Kewajiban Jangka Pendek } \\
\text { Biaya yang masih harus di bayar } \\
\text { Hutang Pajak } \\
\text { Hutang Lainnya } \\
\text { Hutang Usaha }\end{array}$ & $\begin{array}{l}\text { 2).(8).1.13 } \\
\text { 2).(8).1.14 } \\
\text { 2).(8).1.15 } \\
\text { 2).(8).1.16 }\end{array}$ & $\begin{array}{l}229.991 .672,00 \\
278.406 .069,00 \\
168.227 .010,00\end{array}$ & $\begin{array}{r}205.280 .404,00 \\
333.402 .135,12 \\
55.500 .000,00 \\
38.750 .000,00 \\
\end{array}$ \\
\hline $\begin{array}{l}\text { Jumlah Kewajiban Jangka } \\
\text { Pendek }\end{array}$ & & 676.624.751,00 & 632.932.539,12 \\
\hline $\begin{array}{l}\text { Kewajiban Lain-lain } \\
\text { Uang Jaminan Langganan } \\
\text { Dana Pembagian Laba }\end{array}$ & $\begin{array}{l}2) .(8) .1 .17 \\
\text { 2).(8).1.18 }\end{array}$ & $\begin{array}{r}151.053 .824,00 \\
78.660 .766,91 \\
\end{array}$ & $243.915 .105,80$ \\
\hline Jumlah Kewajiban Lain-lain & & 229.714.590,91 & $243.915 .105,80$ \\
\hline Jumlah Kewajiban & & $906.339 .341,91$ & $876.947 .644,92$ \\
\hline
\end{tabular}

\begin{tabular}{|l|l|l|l|}
\hline 1 & 2 & 3 & 4 \\
\hline Ekuitas & & &
\end{tabular}




\begin{tabular}{|l|c|r|r|} 
Penyertaan Pemerintah Daerah & 1.19 & $16.011 .647 .118,00$ & $18.011 .647 .118,00$ \\
Penyertaan Pemerintah & & & \\
Pusat/Provinsi & 1.2 & $17.764 .540 .430,78$ & $17.764 .540 .430,78$ \\
Cadangan Dana & $2) .(11) .1 .21$ & $408.400 .957,98$ & $528.276 .500,51$ \\
Akumulasi Kerugian Taun-tahun & 1.22 & $-13.086 .675 .988,14$ & $-13.086 .675 .988,14$ \\
lalu & 1.23 & $1.652 .547 .226,12$ & $1.643 .011 .744,26$ \\
\hline Laba (Rugi) Tahun Berjalan & & $\mathbf{2 2 . 7 5 0 . 4 5 9 . 7 4 4 , 7 4}$ & $\mathbf{2 4 . 8 6 0 . 7 9 9 . 8 0 5 , 4 1}$ \\
\hline Jumlah Ekuitas & $\mathbf{2 3 . 6 5 6 . 7 9 9 . 0 8 6 , 6 5}$ & $\mathbf{2 5 . 7 3 7 . 6 4 7 . 4 5 0 , 3 3}$ \\
\hline Jumlah Kewajiban dan Ekuitas & & & \\
\hline
\end{tabular}

Sumber :Data Diolah

Dalam tabel neraca di atas dapat diketahui jumlah asset lancar Dalam tabel neraca di atas dapat diketahui jumlah asset lancar tahun 2012 sebesar Rp 12.467.869.912,78 dan tahun 2013 sebesar Rp 12.987.492.509,68. Jumlah asset tetap tahun 2012 sebesar Rp 11.188.929.173,87 dan tahun 2013 sebesar Rp 12.061.621.257,65. Jumlah asset lain-lain tahun 2013 sebesar Rp 688.533.683,00. Sehingga jumlah asset tahun 2012 adalah Rp 23.656.799.086,65 dan tahun 2013 adalah Rp 25.737.647.450,33. Kemudian jumlah kewajiban jangka pendek tahun 2012 sebesar Rp 676.624.751,00 dan tahun 2013 sebesar Rp 632.932.539,12 Jumlah kewajiban lain-lain tahun 2012 sebesar Rp 229.339.341,91 dan tahun 2013 sebesar Rp 243.915.105,80. Jadi jumlah kewajiban tahun 2012 adalah Rp 906.339.341,91 dan tahun 2013 adalah Rp 876.847.644,92. Jumlah ekuitas tahun 2012 sebesar Rp 22.750.459.744,74 dan tahun 2013 sebesar Rp 24.860.799.805,41. Jadi jumlah kewajiban dan ekuitas tahun 2012 adalah Rp 23.656.799.086,65 dan tahun 2013 adalah Rp 25.737.647.450,33.

Untuk mengetahui pendapatan pada PDAM Tirta Bumi Sentosa Kabupaten Kebumen, di bawah ini akan disajikan tabel laporan laba rugi:

Tabel 2.2 Tabel Laporan Laba Rugi tahun 2012 dan 2013 di PDAM Tirta Bumi Sentosa Kabupaten Kebumen

\begin{tabular}{|c|c|c|c|}
\hline Keterangan & Referensi & Tahun 2012 (Rp) & Tahun 2013 (Rp) \\
\hline 1 & 2 & 3 & 4 \\
\hline \multicolumn{4}{|l|}{ Pendapatan Usaha } \\
\hline Pendapatan Penjualan Air & 2).(2).1 & 11.017.668.000,00 & 11.083.909.300,00 \\
\hline Penjualan Non Air & 2).(2). 2 & $1.211 .291 .420,65$ & $1.936 .055 .518,00$ \\
\hline Jumlah Pendapatan usaha & & 12.228.959.420,65 & 13.019.964.818,00 \\
\hline \multicolumn{4}{|l|}{ Biaya Langsung Usaha } \\
\hline Beban Kantor & 2).(3).2.1 & 4.125.323.626,00 & 4.392.062.734,00 \\
\hline Beban Pemeliharaan & 2).(3).2.2 & $963.921 .115,61$ & $836.674 .188,50$ \\
\hline Beban Pemeliharaan & 2).(3).2.3 & $455.740 .448,00$ & $382.183 .284,86$ \\
\hline Beban Bahan Bakar & 2).(3). 2.4 & $203.953 .142,00$ & $483.798 .581,00$ \\
\hline Beban Bahan Kimia & 2).(3).2.5 & $676.308 .490,25$ & $687.772 .581,00$ \\
\hline 1 & 2 & 3 & 4 \\
\hline Beban Listrik & 2).(3).2.6 & $1.938 .549 .124,00$ & $2.161 .808 .682,00$ \\
\hline Beban Rupa-rupa & 2).(3).2.7 & $712.012 .742,00$ & $945.064 .554,17$ \\
\hline Jumlah Beban Usaha & & 9.075.808.687,86 & $9.889 .364 .554,53$ \\
\hline \multicolumn{4}{|l|}{ Laba Rugi Sebelum } \\
\hline Penyusutan dan Penyisihan & & & \\
\hline Piutang & & $3.153 .150 .732,79$ & $3.130 .600 .263,47$ \\
\hline Beban Penyisihan Piutang & 2).(3). 2.8 & $59.990 .824,32$ & $6.151 .783,00$ \\
\hline Beban Penyusutan & 2).(3). 2.9 & $1.478 .602 .053,80$ & $1.550 .237 .561,07$ \\
\hline
\end{tabular}




\begin{tabular}{|c|c|c|c|}
\hline $\begin{array}{l}\text { Laba Rugi Sebelum } \\
\text { Pendapatn dan Beban } \\
\text { Lain-lain }\end{array}$ & & 1.614.557.854,67 & 1.574.211.019,40 \\
\hline $\begin{array}{l}\text { Pendapatan (Biaya) Lain- } \\
\text { lain }\end{array}$ & & & \\
\hline Pendapatan Lain-lain & 2).(2).2.3 & $377.280 .422,43$ & $432.693 .214,86$ \\
\hline Beban Lain-lain & 2).(3).2.10 & $-63.619 .800,98$ & $-30.490 .354,88$ \\
\hline $\begin{array}{l}\text { Jumlah Pendapatan } \\
\text { (Biaya) Lain-lain }\end{array}$ & & $313.660 .621,45$ & 402.202.859,98 \\
\hline Laba (Rugi) Sebelum Pajak & & $1.928 .218 .476,12$ & $1.976 .413 .879,38$ \\
\hline Pajak Penghasilan Badan & & $-275.671 .250,00$ & $-333.402 .135,12$ \\
\hline Laba (Rugi) Bersih & & 1.652.547.226,12 & $1.643 .011 .744,26$ \\
\hline
\end{tabular}

Sumber :Data Diolah

Pada tabel laporan laba rugi di atas terdapat pendapatan usaha tahun 2012 adalah sebesar $\mathrm{Rp}$ 12.228.959.420,65 dan tahun 2013 adalah sebesar Rp 13.019.964.818,00. Pendapatan usaha diperoleh dari pendapatan penjualan air dan pendapatan penjualan non air. Jumlah beban usaha tahun 2012 sebesar Rp 9.075.808.687,86 dan tahun 2013 sebesar Rp 9.889.364.554,53. Jumlah pendapatan lainlain tahun 2012 sebesar Rp 313.660.621,45 dan tahun 2013 sebesar Rp 402.202.859,98. Laba rugi sebelum pajak tahun 2012 sebesar Rp 1.928.218.476,12 dan tahun 2013 sebesar Rp 1.976.413.879,98. Laba rugi bersih pada PDAM Tirta Bumi Sentosa Kabupaten Kebumen tahun 2012 sebesar Rp 1.652.547.226,12 dan tahun 2013 sebesar Rp 1.643.011.744,26.

\section{Analisa, Perhitungan dan Pembahasan}

A. Analisa dan Perhitungan

Dalam menganalisa pengaruh efektivitas pengelolaan piutang atas pendapatan terhadap profitabilitas pada PDAM Tirta Bumi Sentosa Kabupaten Kebumen, penulis menghitung perputaran piutang dan rata-rata piutang serta membahas tentang pendapatan penjualan.

\section{Perhitungan Perputaran Piutang}

Rasio Perputaran piutang (Receivable Turn Over Ratio) digunakan untuk mengukur kemampuan perusahaan dalam menngelola dana yang tertanam dalam piutang yang berputar pada suatu periode tertentu.

Rumus:

\section{Perputaran Piutang $=\frac{\text { Penjualan Kredit }}{\text { Piutang rata-rata }}$}

Perhitungan perputaran piutang pada PDAM Tirta Bumi Sentosa Kabupaten Kebumen tahun 2012 dan 2013 sebagai berikut:

a) Tahun 2012

$$
\begin{gathered}
\text { perputaran piutang }=\frac{\text { penjualan kredit }}{\text { piutang rata-rata }} \\
=\frac{\operatorname{Rp~} 12.228 .959 .420,65}{\operatorname{Rp~} 2.132 .755 .805} \\
=5,7338 \mathrm{kali} \text { dibulatkan }=5,7 \mathrm{kali}
\end{gathered}
$$

Perputaran piutang pada PDAM yang digunakan untuk mengetahui berapa kali dalam satu periode piutang akan kembali menjadi kas pada tahun 2012 adalah sebesar 5,7338 kali atau dibulatkan 5,7 kali.

b) Tahun 2013

$$
\text { perputaran piutang }=\frac{\text { penjualan kredit }}{\text { piutang rata-rata }}
$$




$$
\begin{aligned}
= & \frac{\operatorname{Rp} 13 \cdot 019.964 .818}{\operatorname{Rp} 2.459 .374 .425} \\
= & 5,2940 \text { kali dibulatkan }=5,3 \text { kali }
\end{aligned}
$$

Sedangkan perputaran piutang pada PDAM tahun 2013 adalah sebesar 5,2940 kali atau dibulatkan $5,3 \mathrm{kali}$.

Berdasarkan perhitungan diatas menunjukkan bahwa perputaran piutang pada PDAM dari tahun 2012 sampai 2013 mengalami penurunan. Perputaran piutang menurun karena kebijakan dalam penagihan piutang terlalu lunak. Untuk mengelola perputaran piutang perusahaan harus memperbaiki cara penagihan piutangnya dengan memberi batas maksimal untuk pelanggan melakukan pembayaran tagihan yang belum dibayar.

\section{Perhitungan Piutang Rata-Rata}

Piutang rata-rata digunakan untuk mengukur periode rata-rata yang diperlukan untuk mengumpulkan piutang (dalam satu hari).

$$
\text { Pumus: }
$$

Perhitungan piutang rata-rata pada PDAM Tirta Bumi Sentosa Kabupaten Kebumen tahun 2012 dan 2013 sebagai berikut:

a) Tahun 2012

$$
\begin{aligned}
& \text { Piutang rata-rata }=\frac{\text { Piutang rata-rata } \times 360}{\text { Penjualan krdit }} \\
& =\frac{\operatorname{Rp~} 2.132 .755 .805 \times 360}{\operatorname{Rp~} 12.228 .959 .420,65} \\
& =62.7847 \text { hari dibulatkan }=63 \text { hari }
\end{aligned}
$$

Piutang rata-rata yang digunakan untuk mengukur periode rata-rata yang diperlukan untuk mengumpulkan piutang pada tahun 2012 adalah sebesar 62,7847 hari atau dibulatkan 63 hari.

b) Tahun 2013

$$
\begin{aligned}
& \text { Piutang rata-rata }=\frac{\text { Piutang rata-rata } \times 360}{\text { Penjualan krdit }} \\
& =\frac{\operatorname{Rp~2.459.374.425\times 360}}{\operatorname{Rp} 13.019 .964 .818}=68,0013 \text { hari dibulatkan }=69 \text { hari }
\end{aligned}
$$

Sedangkan piutang rata-rata pada tahun 2013 adalah sbesar 68,0013 hari atau dibulatkan 69 hari.

Piutang rata-rata pada perusahaan dari tahun 2012 sampai 2013 adalah semakin besar. Jadi kemungkinan piutang tak tertagihnya semakin besar. Untuk mengelola umur piutang yang semakin besar perusahaan harus menetapkan kebijakan kepada pelanggan untuk membayar tagihan yang belum dibayar tepat waktu dan apabila pelanggan membayar melebihi waktu yang ditentukan maka pelanggan harus membayar denda.

\section{Pendapatan}

PDAM Tirta Bumi Sentosa Kabupaten Kebumen memperoleh pendapatan dari penjualan air bersih.

Rumus:

$$
\text { Rasio piutang atas pendapatan }=\frac{\text { Piutang }}{\text { Total Penjualan }} \times 100 \%
$$

Perhitungan rasio piutang terhadap pendapatan pada PDAM Tirta Bumi Sentosa Kabupaten Kebumen tahun 2012 dan 2013 sebagai berikut:

a) Tahun 2012 


$$
\begin{aligned}
& \text { Rasio piutang terhadap pendapatan }=\frac{\text { Piutang }}{\text { Total Penjualan }} \times 100 \% \\
& =\frac{\text { Rp } 2.132 .755 .805}{\operatorname{Rp~} 12.228 .959 .420,65} \times 100 \% \\
& =0,1744 \%
\end{aligned}
$$

Rasio piutang atas pendapatan digunakan untuk mengukur efektivitas dan efisiensi penggunaan piutang. Piutang atas pendapatan pada PDAM Tirta Bumi Sentosa Kabupaten Kebumen tahun 2012 adalah $0,1744 \%$.

b) Tahun 2013

$$
\begin{aligned}
& \text { Rasio piutang terhadap pendapatan }=\frac{\text { Piutang }}{\text { Total Penjualan }} \times 100 \% \\
& =\frac{\operatorname{Rp~} 2.459 .374 .425}{\operatorname{Rp~} \begin{array}{l}
13.019 .964 .818 \\
=0,1888 \%
\end{array}} \times 100 \%
\end{aligned}
$$

Sedangkan piutang atas pendapatan pada PDAM Tirta Bumi Sentosa Kabupaten Kebumen tahun 2013 adalah $0,1888 \%$.

Rasio piutang terhadap pendapatan pada PDAM Tirta Bumi Sentosa Kabupaten Kebumen dari tahun 2012 sampai 2013 mengalami kenaikan. Piutang naik sehingga pendapatan perusahaan berkurang.

\section{B. Kebijakan PDAM}

PDAM Tirta Bumi Sentosa Kabupaten Kebumen cara mengelola piutangnya dengan cara memberikan kebijakan pembayaran tagihan piutang kepada pelangga yaitu dengan memberikan jangka waktu pembayaran tagihan piutang yang mengharuskan pelanggan membayar piutangnya kepada perusahaan sesuai dengan waktu yang telah ditentukan oleh perusahaan. PDAM Tirta Bumi Sentosa Kabupaten Kebumen menetapkan aturan batas waktu pembayaran tagihan adalah setiap tanggal dua puluh. Apabila pelanggan membayar tagihan tersebut melewati waktu yang telah ditentukan maka pelanggan akan dikenai denda sebesar Rp 5.000,00 setiap bulan.

Pengelolaan piutang pada PDAM Tirta Bumi Sentosa Kabupaten Kebumen belum efektif karena masih banyak pelanggan yang belum membayar tagihannya kepada perusahaan. Apabila pelanggan banyak yang tidak membayar tagihannya maka pendapatan perusahaan menurun.

Aturan yang diberlakukan oleh PDAM Tirta Bumi Sentosa Kabupaten Kebumen apabila pelanggan tidak membayar tagihannya, yang pertama adalah dengan penutupan saluran air PDAM tersebut. Penutupan dilakukan apabila pelanggan tidak membayar tagihan air bersih selama tiga bulan kepada perusahaan. Kemudian aturan yang kedua adalah dengan pembongkaran yaitu membongkar saluran air bersih PDAM tersebut.

\section{Pembahasan}

Dilihat dari tabel laba rugi, laba rugi perusahaan dari tahun 2012 sampai 2013 menurun dan apabila dihitung dalam persentase penurunannya adalah sebagai berikut:

$$
\begin{aligned}
& \frac{\text { Laba Tahun ke n - Laba Tahun (n-1) }}{\text { Laba Tahun (n-1) }} \times 100 \% \\
& \frac{\text { Laba Tahun 2013-Laba Tahun } 2012}{\text { Laba Tahun } 2012} \times 100 \% \\
& \frac{\text { Rp 1.643.011.744,26-Rp 1.652.547.226,12 }}{\text { Rp } 1.652 .547 .226,12} \times 100 \% \\
& =\frac{\text { Rp }-9535481,86}{\text { Rp } 1.652 .547 .226,12} \times 100 \% \\
& =-0,00577 \times 100 \% \\
& \quad=-0,577 \%
\end{aligned}
$$




$$
=-0,6 \%
$$

Dari perhitungan di atas diketahui bahwa laba perusahaan menurun 0,6\%. Profitabilitas sangat penting untuk menjalankan perusahaan dan yang menjadi faktor penting perusahaan dalam mengambil kebijakan atau keputusan.

Pengelolaan piutang atas pendapatan di PDAM Tirta Bumi Sentosa Kabupaten Kebumen masih kurang efektif dan efisien, serta kebijakan dalam penagihan piutang terlalu lunak, hal ini bisa dilihat pada laporan keuangan dimana angka piutang setiap tahun selalu meningkat dan menyebabkan pendapatan perusahaan berkurang. Hal tersebut bisa diketahui di antaranya dari perputaran piutang di PDAM Tirta Bumi Sentosa Kabupaten Kebumen tahun 2012 sebesar 5,7338 kali atau di bulatkan 5,7 kali dan tahun 2013 sebesar 5,2940 kali atau dibulatkan 5,3 kali berarti mengalami penurunan. Perputaran piutangnya menurun berarti dana yang tertanam dalam piutang semakin tinggi, sehingga keuntungan perusahaan berkurang.

Kemudian untuk rata-rata piutangnya tahun 2012 setelah dibulatkan adalah 63 hari dan tahun 2013 setelah dibulatkan adalah 69 hari, menandakan semakin panjang umur piutangnya. Semakin lama waktu pengumpulan piutang, maka semakin lama untuk melunasi piutang. Sehingga perusahaan mendapatkan keuntungan yang sedikit. Selain itu, rasio piutang atas pendapatan PDAM Tirta Bumi Sentosa Kabupaten Kebumen tahun 2012 adalah $0,1744 \%$ dan tahun 2013 adalah $0,1888 \%$ berarti mengalami kenaikan. Piutang bertambah dan pendapatan atau keuntungan berkurang. Apabila piutang bertambah bisa terjadi semakin banyak piutang tak tertagihnya. Apabila dilihat dari perputaran piutang pada PDAM Tirta Bumi Sentosa Kabupaten Kebumen dari tahun 2012 sampai tahun 2013 mengalami penurunan, jadi pengelolaan piutang pada PDAM Tirta Bumi Sentosa Kabupaten Kebumenbelum efektif sehingga berpengaruh terhadap profitabilitas perusahaan yang kurang baik. Pengelolaan piutang berpengaruh terhadap profitabilitas perusahaan. Apabila piutang tidak efektif maka profitabilitas kurang baik. Apabila pelanggan tidak membayar tagihannya maka piutang akan bertambah dan mengakibatkan pendapatan perusahaan menurun. Apabila piutang bertambah bisa terjadi semakin banyak piutang tak tertagihnya.

\section{E. KESIMPULAN DAN SARAN}

\section{Kesimpulan}

Kesimpulan yang dapat diberikan oleh penulis yang berdasarkan dari penelitian pengaruh efektivitas pengelolaan piutang atas pendapatan terhadap profitabilitas pada PDAM Tirta Bumi Sentosa Kabupaten Kebumen adalah sebagai berikut:

1. Untuk mengelola piutang yang semakin besar perusahaan memberikan kebijakan kredit yaitu dengan memberikan jangka waktu kredit yang mengharuskan pelangaan membayar piutangnya kepada perusahaan sesuai dengan jangka waktu yang telah ditetapkan oleh perusahaan.

2. Pengelolaan piutang pada PDAM Tirta Bumi Sentosa Kabupaten Kebumen belum efektif sehingga berpengaruh terhadap profitabilitas perusahaan yang kurang baik.

3. Pengelolaan piutang berpengaruh terhadap profitabilitas perusahaan. Apabila piutang tidak efektif maka profitabilitas kurang baik. Hal ini karena perusahaan mendapatkan pendapatan dari penjualan air bersih tersebut

\section{Saran}

Berdasarkan hasil penelitian pengelolaan piutang atas pendapatan pada PDAM Tirta Bumi Sentosa Kabupaten Kebumen, maka dapat dikemukakan saran yang mungkin berguna bagi PDAM

Tirta Bumi Sentosa Kabupaten Kebumen, yaitu

1. untuk mengendalikan piutang dan mengantisipasi adanya piutang yang tak tertagih maka perusahaan perlu memberikan kebijakan dalam pengihan piutang dimana perusahaan berharap agar pelanggan menyetor pembayarannya tepat waktu.

2. Memberikan sanksi atau denda yang ketat terhadap pelanggan yang membayar tagihannya melebihi batas waktu atau yang sering menunggak pembayarannya.

3. Agar pendapatan bertambah perusahaan harus meningkatkan piutang dengan cara memberikan kebijakan dengan menutup atau membongkar saluran air agar tidak semakin banyak piutang tak tertagihnya.

4. Membentuk pelayanan kepada pelanggan yang lebih bagus. 


\section{F. DAFTAR PUSTAKA}

Giri, Efraim Ferdinan.2012.Akuntansi Keuangan Menengah 1 Perspektif IFRS. Edisi 1.Yogyakarta:UPP STIM YKPN.

Harahap, Sofyan Syafri. 2008. Analisa Kritis atas Laporan Keuangan.Jakarta: PT. Raja Grafindo Persada Martono,Agus. 2002. Manajemen Keuangan. Edisi 1 .Penerbit: Graha Ilmu. Yogyakarta.

Mujati Suaidah, Yuniep. 2008. Analisis Pengaruh Utang Jangka Pendek Dan Perputaran Piutang Terhadap Profitabilitas Perusahaan.

Mulya,Hadri. 2010.Memahami Akuntansi Dasar. Edisi 2.Jakarta : Mitra Wancana Media.

Sutrisno.2008. Manajemen Keuangan : Teori, konsep dan Aplikasi. Edisi Pertama .Yogyakarta: Ekonisia. Syamsudin, Lukman. 2007. Manajemen Keungan Perusahaan, Konsep Aplikasi dalam Perencanaan, Pengawasan dan Pengambil Keputusan .Jakarta:.Raja Grafindo.

Warren, Reeve, Fess. 2005.Accounting Pengantar Akuntansi. Jakarta : Salemba Empat. Wiksuana, Bagus, dkk. 2001. Manajemen Keuangan. Denpasar

:UPT Penerbit Universitas Udayana.

http://adaddanuarta.blogspot.co.id/2014/11/profitabilitas-menurut-para-ahli.html (Senin, 26 0ktober 2015, Pukul 08.42)

http://kebonharjo2.blogspot.co.id/2013/07/pengertian-piutang-dan-jenis-jenis.html (Jumat, 5 Februari 2016, Pukul 17.30) 